\title{
Knowledge and Practices Regarding Menstrual Hygiene among Mentally Retarded Females at Schools
}

\author{
MONA S. ATRESS, M.Sc.; NAWAL A. FOUAD, D.N.Sc. and HEBA M. HAMAD, D.N.Sc. \\ The Department of Community Health Nursing, Faculty of Nursing, Cairo University
}

\begin{abstract}
Background: Unhygienic practices during menstruation among mentally retarded female students' endanger their reproductive health and expose them to reproductive diseases such as reproductive tract infections and pelvic inflammatory diseases.

Aim: This study aimed to assess knowledge and reported practices regarding menstrual hygiene among mentally retarded female students' at Cairo Governorate preparatory mainstream schools.

Design: A descriptive exploratory research design was utilized in this study.

Setting: Three educational departments were selected randomly from all educational departments at Cairo Governorate. All schools that are affiliated to these three educational departments were included in the study. Total number was 14 preparatory mainstream schools.
\end{abstract}

The study Sample: Convenient sample of 100 mentally retarded female students' from the fourteen selected schools were included in the study.

Tool for Data Collection: One tool consisted of three parts was used to collect data pertinent to the study. First part: Student questionnaire about demographic characteristics of the mentally retarded female students' and their parents. Second part: Data about level of knowledge regarding menstruation and menstrual hygiene. Third part: Data about reported practices regarding menstrual hygiene.

Results: Study result revealed that $86 \%$ of the mentally retarded female students' had poor knowledge regarding menstrual hygiene, while $14 \%$ of them had good knowledge. Regarding reported practices $80 \%$ of them had poor practice, while $20 \%$ had good practice. There were statistically significant relationship between practice scores and the Intelligence Quotient (IQ) with $p$-value $=0.006$. There were statistically significant relationship between practice scores and family history of mental retardation with $p$-value $=0.001$, between knowledge scores and students' IQ with $p$-value $=0.001$ and between total knowledge scores and total practice scores with $p$-value $=0.042$.

Correspondence to: Dr. Mona S. Atress, The Department of Community Health Nursing, Faculty of Nursing, Cairo University
Conclusion: The study concluded that, the majority of mentally retarded females have poor knowledge and practice regarding menstrual hygiene.

Recommendations: The study recommended that implementation of educational program to parents and mentally retarded female students' about the menstruation and good menstrual hygiene is very important.

Key Words: Mental retardation - Menstruation - Menstrual hygiene - Practice - Knowledge.

\section{Introduction}

MENTAL retardation is a generalized neurodevelopment disorder characterized by significantly impaired intellectual, adaptive, significantly reduced ability to understand new or complex information, to learn and apply new skills (impaired intelligence) and reduce ability to cope independently (impaired social functioning) [1]. Mental retardation is defined as the intelligence quotient "IQ" score under 70, in addition to deficits in two or more adaptive behaviors that affect every day, general living, focused entirely on cognition [2].

Adolescence is the period in human growth and development that occurs after childhood and before adulthood, from ages 10 to 19 years old. It represents one of the critical transitions in the life span and is characterized by a tremendous pace in growth and change that is second only to that of infancy. The biological determinants of adolescence are universal, however, the duration and defining characteristics of this period may vary across time, cultures, and socioeconomic situations [3]. It is also a period of personal development during which adolescent person must establish a personal sense of individual identity and feeling of self worth which include an alteration of his or her body image, adaptation to more, mature intellectual abilities, adjustment to society demands for behavioral maturity, internalizing a personal value system, and preparing for adult roles [4] 
Menstruation is a normal female physiological phenomenon. The occurrence of regular menstruation is a strong evidence of a female's reproductive health. The menstrual cycle in females is an indicator of changes occurring during the adolescent stage. The menstrual cycle is a component of natural changes that occur in the uterus and ovaries as an essential part of sexual reproduction and it is accompanied by a change in the physical, psychological and social aspects of a female's life [5] The first menstruation also called as menarche is an indicator of developmental maturation in female whose arrival determines the transition from being a child to being a teenager. It occurs between the ages of 11 and 15 years old with an average age of 13 years old [6].

Menstrual hygiene, which refers to the effective management of menstrual bleeding, is an important aspect of reproductive health, which, if not handled appropriately, can cause urinary tract infection, pelvic inflammatory diseases and vaginal thrush, as well as bad odor, ultimately shame, leading to infringement on the girls' dignity [7]. Females having knowledge regarding menstrual hygiene are less vulnerable to RTI and its consequences. Therefore, improving adolescent knowledge about menstruation helps in decreasing suffering of reproductive tract infection [8].

Menstrual hygiene issues are a common point of discussion in mentally retarded females and their families. Menstrual hygiene problems may be closely related to self care skills; therefore, appropriate self care training for females with mental retardation is necessary in order to prevent hygiene difficulties. To teach the self-care skills, it may be necessary to identify what types of selfcare problems the females with mental retardation have struggled [9].

School health nurses can prevent hygienic problems through providing education to mentally retarded adolescent females about menstruation and hygienic care during menstruation. School health nurses are able to support the efforts of administration to provide educational programs to parents that help their daughters to know sufficient information regarding menstruation and its hygienic care, and monitoring of their daughters. School health nurses are also able to serve on curriculum committees, identifying, advocating and implementing educational programs regarding menstruation and its hygienic care within the school community. School health nurses have varying responsibilities for curricula related to menstruation. The school health nurses are usually a source of information on these subjects whether employed full-time in school health or also participating in other nursing roles in the community [10].

\section{Significance of the study:}

In Egypt, Academy of Scientific Research \& Technology [11] reported that no studies were done in the area of knowledge and practices regarding menstrual hygiene among mentally retarded females at schools, so conducting this study will add to the body of nursing knowledge in the area of School Health Nursing regarding the menstrual hygiene. The study will help nurses to assess level of knowledge and practices regarding menstrual hygiene among mentally retarded females at schools. Results of this study will be beneficial for school health nurses to design and conduct health education programs to mentally retarded female students to ensure effective menstrual hygiene and to reduce gynecological problems such as Reproductive Tract Infection (RTI) and its consequences. The results of this study will also raise awareness of professionals regarding the mentally retarded female students to promote their health and to satisfy their needs regarding menstrual hygiene.

\section{Subjects and Methods}

\section{Research questions:}

1- What is the level of knowledge regarding hygienic care during menstruation among mentally retarded female students at Cairo Governorate preparatory mainstream schools?

2- What are the reported practices regarding hygienic care during menstruation among mentally retarded female students at Cairo Governorate preparatory mainstream schools?

Study design: Descriptive exploratory design was utilized to fulfill the aim of the study. As stated by Polit \& Beck [12] exploratory design provides researcher with a better understanding of the problem, identifying the current problems with current practice, observe, describe and document aspects of a situation.

Sample: A convenient sample of 100 mentally retarded female students from 14 schools representing 3 randomly selected educational departments.

Inclusion criteria: Mild mentally retarded adolescent females (IQ level 55-70), menstruating, enrolled in mainstream schools, able to communicate, and independent in hygienic care during menstruation.

Setting: This study was conducted in Governmental girls' preparatory mainstream schools at 
Cairo Governorate. There were thirty two Educational Departments at Cairo Governorate during 2017. Ten percent of these Educational Departments were included in the study, which were three Educational Departments, there departments were selected randomly. All schools that were affiliated to these three Educational Departments were included in the study. Total number was 14 preparatory mainstream schools. These schools were as follow: El-Maadi Educational Department (six schools), El-Sahel Educational Department (four schools), and Ain-Shams Educational Department (four schools). The mainstream schools refer to schools that admit children with different types of disabilities together with normal children in the same class. This study focuses on children with IQ level ranging between 55-70 and they are able to do the same work and duties of normal students with the presence of special education services [13].

Tool for data collection: One tool (mentally retarded female students' questionnaire) was used for data collection that was designed by the investigator after extensive review of literature. This tool consists of three parts.

Part I: Demographic characteristics of the mentally retarded female students:

This part included demographic data of the mentally retarded female students and their parents. It consisted of 10 questions such as, "age, parents' occupation and level of education" there were 5 questions regarding the age of starting of menstruation, medical history of mental retardation in the family, the intelligence quotient "IQ" level, source of information about menstruation and health education about menstruation at school.

Part II: Mentally retarded female students' knowledge about menstruation and menstrual hygiene.

It included 15 questions, the first four questions were multiple choice questions regarding general information about menstruation such as" definition of menstruation" and from fifth question to fifteenth question were open ended questions regarding knowledge about menstrual hygiene such as "definition of menstrual hygiene and importance of menstrual hygiene".

Part III: Reported practices of mentally retarded female students about menstrual hygiene.

It included total number 25 questions. Most of these questions (23) were multiple choice questions concerned with methods of washing, dryness of genital area, removal of pubic hair, type of pads that used during menstruation, frequency of changing pad, bathing during menstruation, and hand washing

Procedures: The formal approval was obtained from Ethics Committee of Scientific Research in Faculty of Nursing, Cairo University. Also formal approval was obtained from the Central Agency for Public Mobilization and Statistics (CAPMAS), Ministry of Education, Cairo Educational Directorate and three Educational Departments "AinShams", "El-Sahel" and "El-Maadi" Educational Departments. Also permission was taken orally from the directors of all preparatory mainstream schools that are affiliated to the three Educational Departments. Mentally retarded female students were asked to participate in the study, and the investigator explained the aim of the study to all female students. Also written consent was obtained from the parents of female students and oral consents then were obtained from the female students to participate in the study. Data were collected from October till November 2016, three days/week. Data were collected through face to face interviewing with students, data were collected during break time or sports time. The time spent to fill the tool ranged between 20 to 30 minutes according to the needed time for students to comprehend the questions.

Ethical considerations: Primary approval was obtained from the Research Ethics Committee at Faculty of Nursing, Cairo University. The investigator informed mentally retarded female students about the purpose and nature of the study. The investigator emphasized that participation in this study is voluntary; each subject has the right to withdraw from the study when she wants. Anonymity and confidentiality was assured through coding of the data. Parents were assured that this data will not be reused in another research without their permission, and the data collected will be used only for the research. Written consent was obtained from the parents of female students and oral consents then were obtained from the female students to participate in the study.

Statistical analysis: Upon completion of data collection the data were scored, tabulated, analyzed by computer using the "Statistical Package for the Social Science"(SPSS) Version 20. Data were statistically described in terms of means, standard deviations, range, frequencies and percentages when appropriate. Relations between different numerical variables were tested using Pearson 
correlation. ANOVA test was used to test relations between demographic variables and knowledge and practice. $p$-values equal to or less than 0.05 was considered statistically significant and 0.001 or less was considered as highly statistically significant.

\section{Results}

Demographic characteristics of the study sample:

Table (1): Percentage distribution of the mentally retarded female students according to their demographic characteristics $(n=100)$.

\begin{tabular}{lll}
\hline Demographic characteristics & No. & $\%$ \\
\hline Age $($ mean $\pm S D):$ & \multicolumn{2}{c}{$13.6 \pm 0.51$} \\
13-14 & 93 & 93.0 \\
15-16 & & 7.0 \\
Mother's education: & 32 & \\
Can't read or write & 37 & 32.0 \\
Read and write & 6 & 37.0 \\
Primary school & 23 & 23.0 \\
Secondary school & 2 & 2.0 \\
College and above & & \\
Mother's occupation: & 10 & 10.0 \\
Employee & 10 & 10.0 \\
Worker & 80 & 80.0 \\
House wife & & \\
Care giver at home: & 6 & 6.0 \\
Father & 58 & 58.0 \\
Mother & 35 & 35.0 \\
Both parents & 1 & 1.0 \\
Sibling & & \\
\hline
\end{tabular}

Table (1) reveals that $93 \%$ of the mentally retarded female students' aged between 13-14 years old, with mean age of $13.6 \pm 0.51$ years. Regarding mother's educational level, (Table 1) also depicts that, $37 \%$ of the mentally retarded female students' mother's can read and write, while $32 \%$ can't read and write. Regarding mother's occupation, (Table 1 ) indicates that $80 \%$ of mentally retarded female students' mother's were housewives.

Knowledge of the study sample regarding menstrual hygiene:

Table (2): Percentage distribution of the mentally retarded female students according to their knowledge about menstrual hygiene $(n=100)$.

\begin{tabular}{lll}
\hline Knowledge items & No. & $\%$ \\
\hline Definition of menstrual hygiene: & 98 & 98.0 \\
$\quad$ Incomplete answer & 2 & 2.0 \\
$\quad$ Complete answer & & \\
Importance of menstrual hygiene: & 32 & 32.0 \\
$\quad$ Don't know & 20 & 20.0 \\
$\quad$ Wrong answer & 43 & 43.0 \\
Incomplete answer & 5 & 5.0 \\
Complete answer & & \\
Health problems of poor menstrual hygiene: & 35 & 35.0 \\
Don't know & 30 & 30.0 \\
Wrong answer & 35 & 35.0 \\
$\quad$ Correct answer & & \\
\hline
\end{tabular}

Table (2) depicts that $98 \%$ of the mentally retarded female students' defined menstrual hygiene incorrectly. Regarding the importance of menstrual hygiene the same table also shows that, $43 \%$ of the mentally retarded female students' mentioned incomplete answer regarding importance of menstrual hygiene. Regarding health problems of poor menstrual hygiene, the same table also declares that $35 \%$ of the mentally retarded female students' reported correct answer regarding health problems of poor menstrual hygiene.

Percentage distribution of mentally retarded female students regarding their total knowledge level about menstrual hygiene

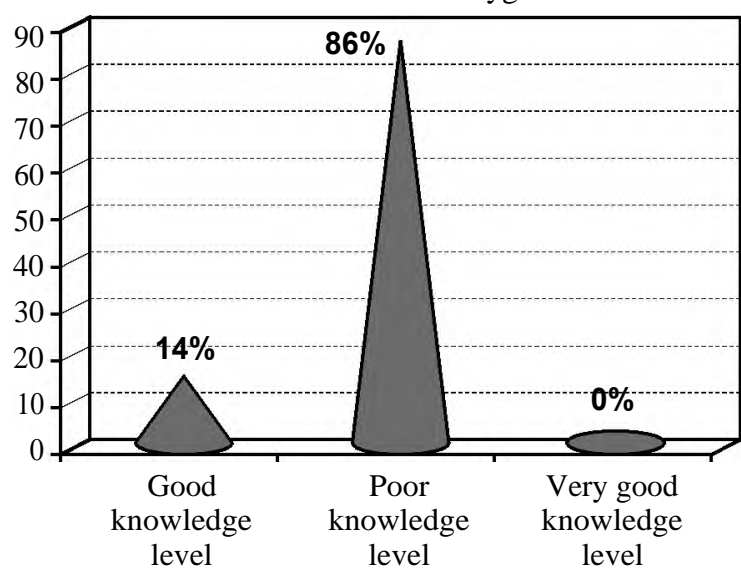

Fig. (1): Distribution of the mentally retarded female students' according to their knowledge level about menstruation and menstrual hygiene.

Fig. (1) indicates that $86 \%$ of the mentally retarded female students' had poor knowledge and $14 \%$ of them had good knowledge regarding menstrual hygiene.

Reported practices of the study sample regarding menstrual hygiene:

Table (3): Percentage distribution of the mentally retarded female students' according to their reported practices about menstrual hygiene $(n=100)$.

\begin{tabular}{lcc}
\hline Practice items & No. & $\%$ \\
\hline Type of pads used during menstruation: & \multicolumn{3}{c}{} \\
$\quad$ Sanitary pad & 40 & 60.0 \\
Cloth pad & \multicolumn{2}{c}{$2 \pm 0.9$} \\
Frequency of pad change (mean \pm SD): & 14 & 14.0 \\
1 time daily & 38 & 38.0 \\
2 times daily & 32 & 32.0 \\
3 times daily & 16 & 16.0 \\
4 times daily or more & & \\
Drying genital area using clean towel each & & \\
time using bathroom during menstruation: & 67 & 67.0 \\
$\quad$ Yes & 21 & 21.0 \\
No & 12 & 12.0 \\
$\quad$ Sometimes & & \\
\end{tabular}


Table (3) indicates that $60 \%$ of the study sample was using sanitary pads during menstruation. Regarding changing pad during menstruation, (Table 3 ) indicates that $38 \%$ of the study sample stated that they changed pads 2 times daily. Regarding drying of the genital area, (Table 3 ) declares that $67 \%$ of the study sample stated that they dried the genital area each time using bathroom during menstruation.

Percentage distribution of mentally retarded female students regarding their reported total practices level about menstrual hygiene

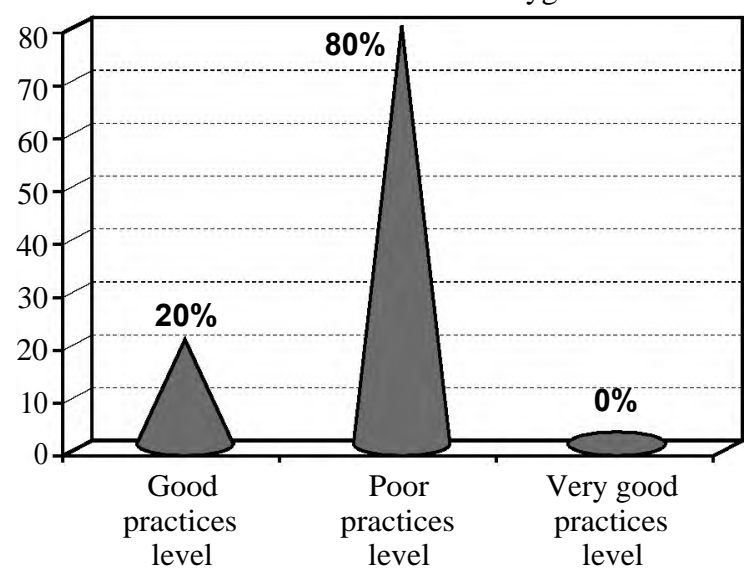

Fig. (2): Distribution of the mentally retarded female students according to their practice level about menstrual hygiene.

Fig. (2) indicates that $80 \%$ of the mentally retarded female students had reported poor practice, whereas $20 \%$ of them had reported good practice.

Relationship between the study variables:

Table (4): Relationship between some demographic characteristics and both knowledge and reported practice scores of the study sample $(n=100)$.

\begin{tabular}{|c|c|c|c|c|}
\hline \multirow[b]{2}{*}{ Variables } & \multicolumn{2}{|c|}{ Knowledge } & \multicolumn{2}{|c|}{ Practice } \\
\hline & $\begin{array}{c}\text { F- } \\
\text { value }\end{array}$ & $\begin{array}{c}p- \\
\text { value }\end{array}$ & $\begin{array}{c}\text { F- } \\
\text { value }\end{array}$ & $\begin{array}{c}p- \\
\text { value }\end{array}$ \\
\hline - IQ level & 2 & $0.001 *$ & 5.4 & $0.006 *$ \\
\hline $\begin{array}{l}\text { - Family history of } \\
\text { mental retardation }\end{array}$ & 0.2 & 0.6 & 11 & $0.001 *$ \\
\hline
\end{tabular}

Table (4) shows that there is a statistically significant relationship between reported practice scores and the IQ level with $p$-value $=0.006$. Also there was a statistically significant relationship between reported practice scores and family history of mental retardation with $p$-value $=0.001$. There was a statistically significant relationship between knowledge scores and IQ level with $p$-value $=0.001$.
Table (5): The relationship between knowledge scores and practice scores $(n=100)$.

\begin{tabular}{lccccc}
\hline \multirow{2}{*}{ Relationship } & \multicolumn{2}{l}{ Total knowledge } & & \multicolumn{2}{c}{ Total practice } \\
\cline { 2 - 3 } \cline { 5 - 6 } & $\begin{array}{c}\text { Pearson } \\
\text { relation } \\
\text { coefficient }\end{array}$ & \begin{tabular}{c}
$p$ value \\
\cline { 5 - 6 }
\end{tabular} & & $\begin{array}{c}\text { Pearson } \\
\text { relation } \\
\text { coefficient }\end{array}$ & $\begin{array}{c}p \text { - } \\
\text { value }\end{array}$ \\
\hline $\begin{array}{l}\text { Total knowledge } \\
\text { Total practice }\end{array}$ & 0.32 & $0.042^{*}$ & & 0.32 & $0.042 *$ \\
\hline
\end{tabular}

Table (5) reveals that there is a statistically significant relationship between total knowledge scores and total practice scores with $p$-value $=0.042$.

\section{Discussion}

The result of the current study revealed that the majority of the mentally retarded female students aged between 13-14 years old with mean age were 13.6 \pm 0.51 . This result was in agreement with the result of a study done by Altundag and Calbayram, [14] in Turkey on 77 of the intellectually disabled female students', aimed to teach pad replacement skills to intellectually disabled adolescent female students during their menstruation. It was found that more than half of the intellectually disabled females aged between 13-14 years old. This result is mainly because the two studies were conducted on adolescent females having menstruation.

This current study indicated that more than one third of the mentally retarded female students' mothers can read and write. This result was in contrast with a study done by Chou \& Luzy, [15] on 13 intellectually disabled females at Taiwan aimed to explore their experiences during menstruation. They found that more than two fifths of intellectually disabled mothers $(41 \%)$ had primary education.

The current study showed that, the majority of the mentally retarded female students' mothers were housewives. The result of the current study was supported by a study done by Chou \& Luzy [15]. Who found that, more than half of the intellectually disabled female mothers $(55 \%)$ were housewives. Also in the same study it was found that the mothers were the main caregiver at home. This agreed with the result of the current study which indicated that mothers were the main caregiver at home for mentally retarded female students'.

The current study depicted that more than half of the mentally retarded female students defined the menstrual hygiene as bathing and washing the genital area. This result doesn't completely agree 
with Leutar and Mihokovic, [16] who examined the level of knowledge about sexuality of people with mental disabilities at Zagreb, Croatia on 24 of the mentally disabled females. It was found that the majority of the mentally disabled females' $(87.5 \%)$ defined the menstrual hygiene is washing the genital area more frequently during menstruation. The differences between the two results may be due to the difference in the culture.

This study revealed that, around one third of the mentally retarded female students' did not know the importance of menstrual hygiene. This result was supported by Nijishma \& Bobby, [17] who identified the measures in the management of hygiene during menstrual cycle of adolescent girls with mental retardation, at Calicut, India, on 60 of the mentally retarded adolescent females. They found that the majority of the mentally retarded adolescent females $(93.3 \%)$ were unaware about the importance of menstrual hygiene. The similarity between the two findings may be related to the similarity of characteristics of the sample in the two studies.

In addition, one third of the mentally retarded female students' did not know the health problems of poor menstrual hygiene. This finding was supported by a study done by Grover, Tracy \& Macgibbon [18], which identified menstrual issues among intellectually disabled, at Australia, on 209 of intellectually disabled females. It was found that, the majority of the intellectually disabled females did not know the health problems of poor menstrual hygiene. The similarity between the two findings may be related to the similarity of characteristics of the sample in the two studies.

Also the present study indicated that the majority of the mentally retarded female students' had poor knowledge. This result was in contrast with a study done by Minz, Horo, Kerketta and Indwar [19], in India, on 30 of the intellectually disabled females' to assess the existing knowledge and practice regarding menstrual hygiene among females with intellectual disability. It was found that one fifth of intellectually disabled females' $(20 \%)$ had poor knowledge. This difference in the results may be due to small sample size.

On the other hand, the current study illustrated that more than half of the mentally retarded female students mentioned that they were using sanitary pads during menstruation. This result was consistent with a study done by Chou et al., [20], on 55 intellectually disabled females, at Taiwan to explore experiences of menstruation among females with an intellectual disability. It was found that around two thirds of the intellectually disabled females (67\%), were using sanitary pads during menstruation. This result reflects wide usage of sanitary pads among adolescent females.

The current study depicted that, around two fifths of the mentally retarded female students changed pads two times daily. This result was in contrast with a study done by Mason \& Cunningham [21], at Liverpool, on 53 of the down syndrome females, to explore some of the issues and challenges faced by females with down syndrome. They found that nearly one quarter of the down syndrome females (24\%) did not want to change pads. The difference between the two findings may be related to differences in culture and sample size.

Around two thirds of the mentally retarded female students dried the genital area each time they used bathroom during menstruation. This result was in contrast with a study done by Altundag and Calbayram, [14]. It was found that the majority of the intellectually disabled females did not dry the genital area each time they used the bathroom during menstruation. This difference between the two findings may be related to cultural differences between two countries.

While the current study showed that the majority of the mentally retarded female students had poor reported practice. This result was in contrast with a study done by Minz, Horo, Kerketta and Indwar, [18]. Who found that more than two fifths of the intellectually disabled females had poor reported practice $(43.33 \%)$. The difference between the two findings may be related to difference in the setting and small sample size.

There is statistically significant relationship between the knowledge scores and the IQ level $p$ value $=0.001$. This result is in the same stream with Talbot \& Langdon [22] who studied on 53 of the intellectually disabled females at Anglia to study sexual knowledge assessment for females with intellectual disabilities. They found that statistically significant relationship between knowledge scores and the IQ level. The similarity between the two findings can be attributed to that the IQ level as the main indicator for good knowledge.

Also, the current study revealed that there is statistically significant relationship between total knowledge scores and total practice scores. This result was supported by a study done by Minz, Horo, Kerketta and Indwar, [19]. Who revealed that a significant relationship between knowledge scores and practice scores. From the investigator point of 
view there could be relationship between total knowledge scores and total practice scores if this study applied in another setting or population.

\section{Conclusion:}

The study concluded that, the majority of mentally retarded females have poor knowledge and practice regarding menstrual hygiene.

\section{Recommendations:}

Based on the current study results, the following recommendations can be made:

- Design educational programs to mentally retarded students regarding menstruation, menstrual hygiene, its importance to raise awareness and practice of good menstrual hygiene.

- Implementing an educational program to mentally retarded students regarding menstruation, menstrual hygiene, its importance to raise awareness and practice of good menstrual hygiene.

- Replication of this study on other groups at the same characteristics except the level of IQs.

\section{References}

1- National Institutes of Health: Definition of Mental Retardation. Available online at: https://www.medicinenet.com/ script/main/art.asp?articlekey=20174, 2017.

2- AWASTHY A.: Sexual Behavior in Adolescents with Intellectual Disability. Central Institute of Psychiatry Ranchi, Jharkhand India. Available online at: www.gkpublication, 2014.

3- World Health Organization: Maternal, Newborn, Child and Adolescent Health, Adolescent Development. Available online at: http://www.who.int/maternal_child_ adolescent/topics/adolescence/development/en, 2014.

4- UNICEF: Adolescent and youth. Available online at: https://www.unicef.org/adolescence/, 2015.

5- WILSON N.: Women Health and Reproductive Health, 2nd edition, Philadelphia Company P.p. 200-10, 2013.

6- BELSKY J., STEINBERG L., HOUTS R. and HALPERNFELSHER B.: The development of reproductive strategy in females: Early maternal harshness early menarche increased sexual risk taking" Developmental Psychology 46, 120-128.Available online at: https://www.medicinenet. com/script/main/art.asp?articlekev=4345, 2013.

8- FERNANDEZ J.: A Study on Awareness regarding Safe and Hygiene Practice amongst School going Adolescent Girls', Wardha district, India Vol: 2. Available online at: http://www.cdc.gov/niosh/pdf. 2013.

8- SUMPTER C. and TORONDEL B.: A Systematic Review of the Health and Social Effects of Menstrual Hygiene Management, 8 (4). Available online at: http://doi.org/ 10.1371/journal.pone.0062004, 2013.

9- PARKER L.: High School Counselors' Attitudes toward the Sexuality of Students with Intellectual Disabilities. Available online at: https://eric.ed.gov/?id=ED552020, 2012.
10- SOMMER M.: Integrating menstrual hygiene management (MHM) into the school water, sanitation and hygiene agenda, the future of water, sanitation and hygiene: Innovation, adaption and engagement in a changing world, Briefing paper, 2011, WEDC, Southborough, UK. Available online at: http://www.mdws.gov.in/sites/default/files/ Menstrual\%20Hygiene\%20Management\%20-, 2014.

11- Academy of Scientific Research and Technology, Egypt, 2016.

12- POLIT F.D. and BECK T.C.: Essential of Nursing Research. Appraising evidence for Nursing Practice, 8 th edition, London Wolter Kluwer Health/Lippincott Williams \& Wilkins, pp. 160. Available online at: http://www. iibio.com, 2014.

13- FLAVELL L.: Preparing to include Special Children in Mainstream School, A Practical Guide, 1 st Edition, pp. 100-5, Lippincott Company London, 2014.

14- ALTUNDAG S. and CALBAYRAM N.: Teaching Menstrual Care Skills to Intellectually Disabled Female Students. Journal of Clinical Nursing. Volume 25, Issue 13 1, Pages 1783-2073.Available online at: http:// onlinelibrary.wiley.com/doi/10.1111/jocn.2016.25.issue13pt14/issuetoc, 2016

15- CHOU YC. and LUZY N.: Caring for a daughter with Intellectual Disabilities in managing Menstruation: A mother's perspective. Journal of Intellectual \& Developmental Disability, March 2012; 37 (1): 1-10. Available online at: http://www.ym.edu.tw/ymnews/253/a1/paper pdf, 2012.

16- MIHOKOVIC M. and LEUTAR Z.: Level of Knowledge about Sexuality of people with Mental Disabilities. Springer Science + Business Media, LLC 2007 25: 93-109, Doi 10.1007/s11195-007-9046 Available online at: http:// . www.springer science.org, 2014.

17- NIJISHMA P.P. and BOBBY K.: Parental Care and Maintenance of Personal Hygiene of Mentally Challenged Children with special reference to Calicut district. Journal of Intellectual Disability. Available online at: http://. www.academia.edu/2007550/parental care and mainte nance_of_personal_hygiene_of mentally_challenged_ children_with_special_reference_to_calicut_district, 2012.

18- TRACY J., GROVER S. and MACGIBBON S.: Menstrual Support for Females with Developmental Disabilities: Survey and Interview of Parents or Caretakers, 39 (2): 54-57. Doi: 10.18773/austprescr.2016.024 PMCID: PMC4917628.Available online at: https://kuscholarworks. . ku.edu/handle/1808/15062, 2016.

19- MINZ K., HORO J., KERKETTA A. and INDWAR K. Effectiveness of Structured Teaching Programmers on Knowledge and Practice regarding Menstrual Hygiene among Female patients' admitted in Central Institute of Psychiatry, India. Available online at: http://www.ekb.eg, 2015.

20- CHOU Y.C., LUZY N., WANG F.T., LAN C.F. and LIN L.C.: Meanings and Experiences of Menstruation: Perceptions of institutionalized women with an Intellectual Disability. Journal of Applied Research in Intellectual Disabilities, 21, 575-84. Doi: 10.1111/j.1468-3148.2008. 00430.x.Available online at: http://onlinelibrary.wiley.com/ doi/10.1111/j.1468-3148.2008.00430.x/pdf, 2013. 
21- MASON L. and CUNNINGHAM C.: An exploration of Issues around Menstruation for women with Down syndrome and their Careers. Journal of Applied Research in Intellectual Disabilities, 21: 257-67. doi:10.1111/j.14683148.2007.00406. Available online at: http://www.ym. edu.tw/ymnews/253/a1/paper.pdf, 2014.
22- TALBOT T.J. and LANGDON P.E.: A revised Sexual Knowledge Assessment tool for people with Intellectual Disabilities: Is sexual knowledge related to sexual offending behavior? Journal of Intellectual Disability Research, 50, 523-31. Available online at: https://kar.kent.ac.uk/ 36136/1/A\%20revised\%20sexual, 2016.

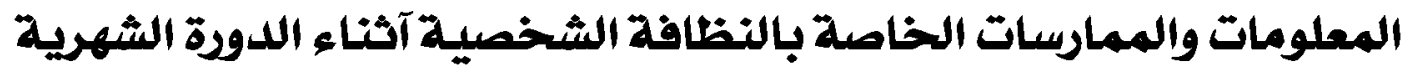

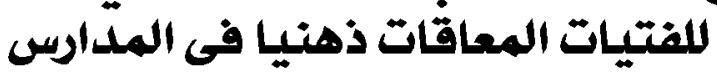

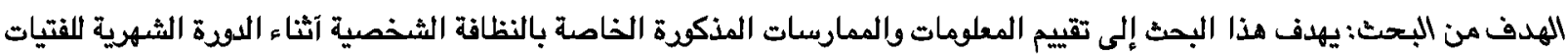
المعاقات ذهنيا في مدارس الدمج الإعدادية بمحافظة القاهرة.

تصميم البحث: إستخدم تصميم الوصفى الإستكثافى ليناسب الغرض من الدراسة descriptive exploratory (A design).

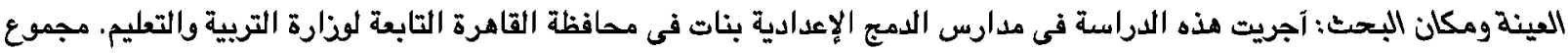
العينة . . الطالبة من الفتيات المعاقات ذهنيا الذين تنطبق عليهم شروط إختيارالعينة.

آدوات البحت: تم تجميع البيانات الخاصة بالدراسة بواسطة إستبيان الفتيات المعاقات ذهنيا عن النظافة الشخصية آثناء الدودة الشهرية وتكونت من ثلاثة آجزاء:

$$
\text { • الجزء الآول: إستبيان الليانات الديموجرافية للفتيات المعاقات ذهنيا وآولياء آمورهن. }
$$

• الجزء الثانىى : آسئلة لتحديد مستوى المعلومات الخاصة بالدوة الثهرية والنظافة الشخصية آثنائها.

• الجزء الثالث: أسئلة لتصديد الممارسات المذكوة الخاصة بالنظافة الشخصية آثناء الدوة الشهرية.

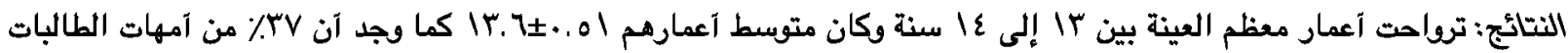

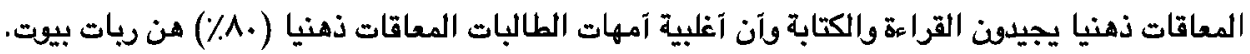

الخلاصةّ: وخلصت الدراسة إلى آن غالية الفتيات المعاقات ذهنيا لديهن مستوى معلومات وممارسات ضعيفة فيما يتعلق بالنظافة الشخصية

$$
\text { آثثاء الدوة الثهرية. }
$$

$$
\text { التوصيات: وإستنادا إلى نتائج الدراسة الحالية، يمكن تقديم التوصيات الآتية: }
$$

• تصميم وتنفيذ برنامج تعليمى الططالبات المعاقات ذهنيا عن الدوة الثهرية والنظافة الشخصية آثناء الدوة الشهرية لتحسين معلوماتهم وممارستهم في هذا المجال.

$$
\text { • تكرار هذه الدراسة في نطاق جغرافى واسع وحجم عينة كبير. }
$$

• تفعيل دود الممرضة الصحية المدرسية كمعلمة للصحة بين الطالبات المعاقات ذهنيا فيما يتعلق بالدوة الثهرية والنظافة الشخصية 